\title{
Cytogenetic analysis of Scinax auratus and Scinax eurydice (Anura, Hylidae) with emphasis on cytotaxonomy
}

\author{
Lídia Nogueira', Fabilene Paim², Débora Diniz², Mirco Solé3, \\ Paulo Affonso'2, Sérgio Siqueira², Iracilda Sampaio'
}

I Instituto de Estudos Costeiros, Universidade Federal do Pará, Alameda Leandro Ribeiro s/n, Aldeia, Bragança, PA, CEP 68600-000 2 Departamento de Ciências Biológicas, Universidade Estadual do Sudoeste da Bahia, Rua José Moreira Sobrinho, s/n - Jequiezinho, Jequié - BA CEP: 45200-000 3 Departamento de Ciências Biológicas, Universidade Estadual de Santa Cruz, Rodovia Ilhéus/Itabuna, km 16, Ilhéus, Bahia, 45662-000, Brazil

Corresponding author: Lidia Nogueira (lidia.nogueira@yahoo.com.br)

Academic editor: N. Tzankov | Received 25 January 2015 | Accepted 8 April 2015 | Published 26 May 2015

http://zoobank.org/F749CC94-CB70-4A50-A2F5-47BF4556F576

Citation: Nogueira L, Paim F, Diniz D, Solé M, Affonso P, Siqueira S, Sampaio I (2015) Cytogenetic analysis of Scinax auratus and Scinax eurydice (Anura, Hylidae) with emphasis on cytotaxonomy. Comparative Cytogenetics 9(2): $227-236$. doi: 10.3897/CompCytogen.v9i2.4593

\begin{abstract}
Scinax Wagler, 1830 is a species-rich genus of amphibians with relatively few detailed chromosomal reports. In this work, cytogenetic analyses of Scinax auratus (Wied-Neuwied, 1821) and Scinax eurydice (Bokermann, 1968) were carried out based on conventional (Giemsa staining, Ag-NOR and C-banding) and cytomolecular (base-specific fluorochrome staining and fluorescence in situ hybridization - FISH of ribosomal probes) techniques. Both species shared the same karyotype, location of active nucleolar organizer regions on pair 11 and GC-rich heterochromatin, as reported for most species in $S$. ruber clade. Interpopulation chromosomal variation was observed in $S$. eurydice, indicating the occurrence of cryptic species. The mapping of $18 \mathrm{~S}$ ribosomal genes by FISH is reported for the first time in both species.
\end{abstract}

\section{Keywords}

Amphibians, chromosomes, FISH, heterochromatin

Copyright Lidia Nogueira et al. This is an open access article distributed under the terms of the Creative Commons Attribution License (CC BY 4.0), which permits unrestricted use, distribution, and reproduction in any medium, provided the original author and source are credited. 


\section{Introduction}

Classic and cytomolecular chromosomal studies have been efficient to infer intra and interspecific relationships in anurans, besides supporting the validation of new and cryptic species (Siqueira et al. 2004; Medeiros et al. 2006; Bruschi et al. 2012; Gruber et al. 2012).

The genus Scinax Wagler, 1830 encompasses 114 species (Frost 2014), but only 39 of them have been karyotyped (Cardozo et al. 2011) while chromosomal mapping of particular DNA sequences is available solely for Scinax fuscovarius (Lutz, 1925) (Kasahara et al. 2003). A review of cytogenetic reports in this genus indicated that all Scinax species present a diploid number $(2 \mathrm{n})$ of 24 and fundamental number of chromosomal arms (FN) equal to 48. In S. catharinae clade, the pairs 1 and 2 are submetacentric and nucleolus organizer regions (NORs) in most species are located on pair 6. This pattern differs from $S$. ruber clade in which the pairs 1 and 2 pairs are metacentric and the NORbearing chromosomes correspond to pair 11 in most species (Cardozo et al. 2011).

S. auratus (Wied-Neuwied, 1821) inhabits rocky areas in Atlantic forest and forest borders in northeastern Brazil (Alves et al. 2004). This species belongs to S. ruber clade and, according to biological and anatomical studies would be related to the following species: Scinax alter (Lutz, 1973), S. cretatus (Nunes \& Pombal, 2011), S. crospedospilus (Lutz, 1925), S. cuspidatus (Lutz, 1925), S. imbegue Nunes, Kwet \& Pombal, 2012, S. juncae Nunes \& Pombal, 2010 and S. tymbamirim Nunes, Kwet \& Pombal, 2012 (Pombal et al. 1995, Alves et al. 2004, Nunes and Pombal 2010, 2011, Nunes et al. 2012, Mercês and Juncá 2012). Cardozo et al. (2011) showed that the karyotype of $S$. alter in unique in $S$. ruber clade because of a distinctive NOR-bearing pair (3q).

S. euridyce (Bokermann, 1968) is also widespread in Brazil with records in five states of northeastern and southeastern Brazil (Bahia, Espírito Santo, Minas Gerais, Rio de Janeiro and São Paulo) (Pombal et al. 1995, Hartmann 2002, Canelas and Bertolucci 2007, Araújo et al. 2009, Magrini et al. 2011). Cytogenetic analyses in samples from southeastern Brazil have shown polymorphic NORs since two specimens presented terminal marks on $11 \mathrm{q}$ while a single female presented interstitial Ag-NORs (Cardozo et al. 2011).

In the present work, we provide new chromosomal data for both $S$. auratus and S. eurydice in order to respond the following questions: (1) Are the NORs observed in 3q of $S$. alter also present in $S$. auratus? (2) Is the polymorphism of NORs previously reported in S. eurydice from southeastern Brazil shared by populations from Bahia? (3) Are there chromosomal differences among geographically distant populations? (4) Can the mapping of $18 \mathrm{~S}$ rDNA by FISH reveal additional non-active NORs previously undetected by silver nitrate staining?

\section{Material and methods}

Five specimens of $S$. auratus and $S$. euridyce were collected for cytogenetic analyses in Jequié, state of Bahia, northeastern Brazil (1351'4"S, 404'52"W) (Table 1). Voucher 
Table I. Analyzed species, number of individuals $(N)$, sex ( $=$ juveniles of undentified sex) and collection site.

\begin{tabular}{|c|c|c|c|}
\hline Species & Voucher & $\mathbf{N}$ & Locality \\
\hline S. auratus & $\begin{array}{l}\text { MZUESC11051 (q), MZUESC11052 (q), MZUESC11053(+), } \\
\text { MZUESC11054 (+), MZUESC11055 (q) }\end{array}$ & 5 & Jequ \\
\hline S. eurydice & 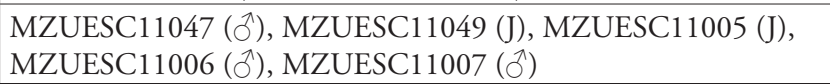 & 5 & Jequ \\
\hline
\end{tabular}

specimens were deposited in the herpetological collection at Universidade Estadual de Santa Cruz - UESC. Mitotic chromosomes were obtained from epithelial cells of intestine as reported by Schmid (1978).

The slides were stained with Giemsa at $10 \%$ in phosphate buffer $(\mathrm{pH} 6.8)$ for about 10 minutes and air dried. For karyotyping, the chromosomes were classified according to centromere position into: $\mathrm{m}$ (metacentric), sm (submetacentric) and st (subtelocentric) following the nomenclature suggested by Green and Session (1991). Active nucleolar organizer regions (Ag-NORs) were detected by silver nitrate staining (Howell and Black 1980) and heterochromatin was visualized by C-banding (Sumner 1972), with slight modifications according to Siqueira et al. (2008). Base-specific fluorochrome with chromomycin $\mathrm{A}_{3}\left(\mathrm{CMA}_{3}\right)$, distamycin (DA) and 4,6-diamidino-2-fenilindole (DAPI) was performed to reveal GC- and/or AT-rich sites (Schmid 1980).

Fluorescence in situ hybridization using $18 \mathrm{~S}$ rDNA probes was carried out according to Pinkel et al. (1986), under stringency conditions of $77 \%$. The ribosomal probes were obtained via PCR of genomic DNA of both species (White et al. 1990, Hatanaka and Galetti 2004). In the case of $S$. eurydice, the probe was labeled with cyanine 3 (Cy3) by nick translation using Bionick Labeling System kit (Invitrogen) according to manufacturer's instructions. In S. auratus, the $18 \mathrm{~S}$ rDNA probe was labeled using fluorescein-12-dUTP (Roche). The chromosomes were counterstained with DAPI and slides were mounted in Vectashield medium (Vector).

The best metaphase spreads were photographed using an Olympus BX51 epifluorescence microscope equipped with digital image capture system (ImagePro Plus - Media Cybernetics) and processed in the software Adobe Photoshop CS 8.0.1.

\section{Results}

S. auratus and S. eurydice presented $2 \mathrm{n}=24$ and $\mathrm{FN}=48$ besides sharing the same chromosomal formula: 16 metacentric (pairs 1, 2, 7, 8, 9, 10, 11 and 12) and eight submetacentric (pairs 3, 4, 5 and 6) chromosomes (Table 2; Fig. 1).

Silver nitrate staining revealed active nucleolus organizer regions (Ag-NORs) at interstitial region of 11q (Fig. 1a-b, box). However, a single homologous presented silver nitrate marks in S. eurydice, being coincident with secondary constrictions in all metaphases (Fig. 1b). 


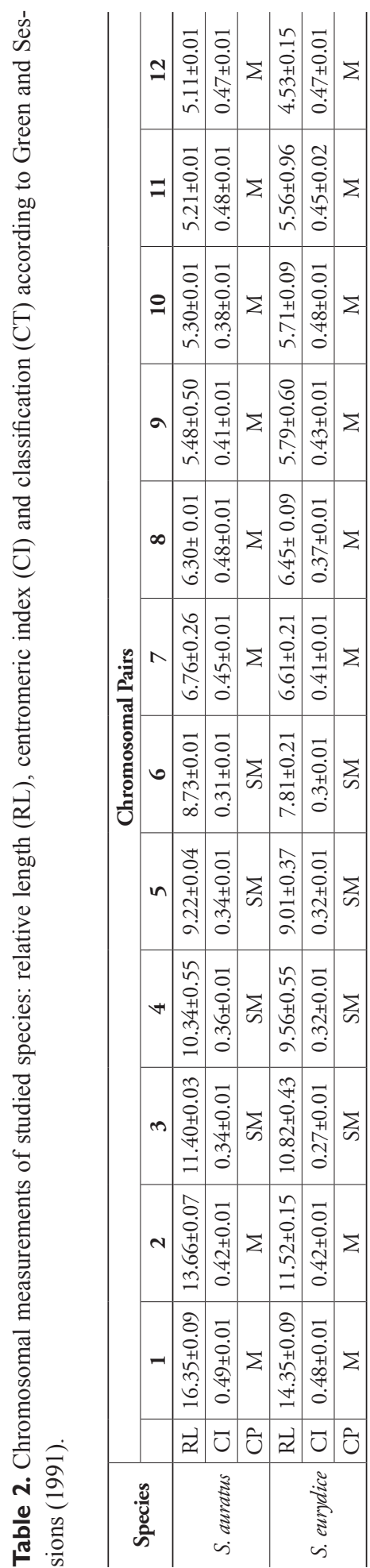




\section{A

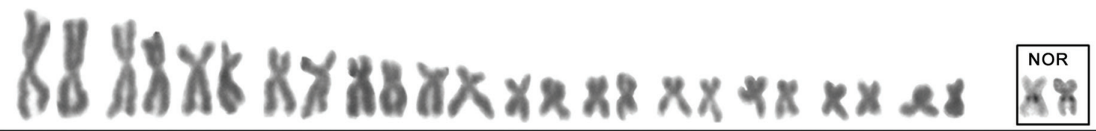
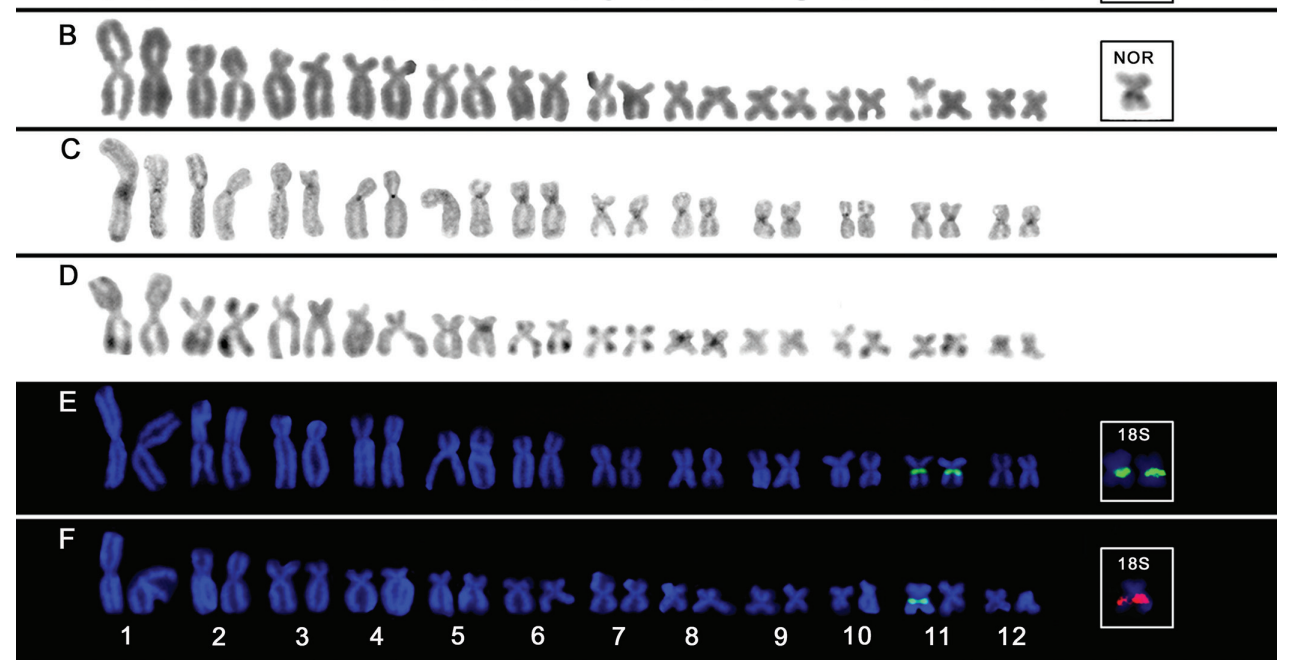

Figure I. Karyotypes of $S$. auratus $(\mathbf{a}, \mathbf{c}, \mathbf{e})$ and $S$. eurydice (b, d, f) after Giemsa-staining (a, b), Cbanding $(\mathbf{c}, \mathbf{d})$ and base-specific fluorochrome staining $(\mathbf{e}, \mathbf{f})$. The NOR-bearing chromosomes after silver nitrate staining and FISH with $18 \mathrm{~S}$ rDNA probes of each species are shown in boxes. Bar $=10 \mu \mathrm{m}$.

Heterochromatin was distributed over centromeric regions of all chromosomes in S. auratus while telomeric C-bands were observed in most chromosomes of $S$. eurydice along with telomeric heterochromatic blocks at centromeric regions of pairs 5 and 8 (Fig. 1c-d). In some metaphases, C-bands were also observed interspersed to NORs at interstitial position of pair 11. After base-specific fluorochrome staining, $\mathrm{CMA}_{3}{ }^{+}$ signals were detected at NORs in both species, indicating the presence of GC-rich heterochromatin segments (Fig. 1e-f).

FISH with $18 \mathrm{~S}$ rDNA probes confirmed the single NOR-bearing pair visualized by silver nitrate staining in the analyzed species (Fig. 1e-f, box).

\section{Discussion}

The karyotypes of $S$. auratus and S. eurydice followed the pattern proposed for Scinax $(2 \mathrm{n}=24$ and FN = 48). Similarly, the karyotype formulae agree with those reported for species within S. ruber clade (Faivovich 2002, Kasahara et al. 2003, Cardozo et al. 2011).

Based on morphological traits and vocalization, $S$. auratus seems to be closely related to Scinax alter, S. cretatus, S. crospedospilus, S. cuspidatus, S. imbegue, S. juncae and S. tymbamirim (Pombal et al. 1995, Alves et al. 2004, Nunes and Pombal 2010, 2011, Nunes et al. 2012, Mercês and Juncá 2012). Karyotypic studies in this group of species are available only for $S$. alter, a distinctive species in $S$. ruber clade by the presence of terminal Ag-NORs on long arms of pair 3 (Cardozo et al. 2011). Even though $S$. 
auratus and $S$. alter shared the same karyotype formulae, the Ag-NORs in the former was identified on pair 11, a plesiomorphic condition reported in most species within $S$. ruber clade. Therefore, cytogenetic studies based on mapping of $18 \mathrm{~S}$ rDNA in closely related species such as $S$. cretatus, S. crospedospilus, S. cuspidatus, S. imbegue, S. juncae and $S$. tymbamirim are encouraged to evaluate whether the presence of NORs among the largest pairs is an autopomorphic condition or a synapomorphy of this subclade.

The NORs were associated with $\mathrm{CMA}_{3}{ }^{+}$signals in both analyzed species, indicating the presence of GC-rich repetitive DNA interspersed with ribosomal genes, as commonly observed in anurans (Ananias et al. 2007, Campos et al. 2008). In spite of this correlation between base-specific fluorochrome and rDNA, the mapping of $18 \mathrm{~S}$ rDNA by FISH is necessary to validate the precise location and number of NORs. In the present study, the FISH results confirmed the presence of a single NOR-bearing pair (11q) in analyzed species (Fig. 1e-f). This pattern has been reported in other species submitted to FISH analyses, with exception of $S$. fuscovarius whose $18 \mathrm{~S}$ rDNA signals were mapped onto pair 12 (Kasahara et al. 2003). Nonetheless, Cardozo et al. (2011) stated that the NOR-bearing pair in S. fuscovarius actually corresponds to the $11^{\text {th }}$ pair, once the smallest chromosomal pairs in Scinax are hardly distinguished.

The specimens of S. eurydice from the state of São Paulo, southeastern Brazil (Cardozo et al. 2011) and those analyzed in the present study had the same karyotype formulae, but different patterns in heterochromatin distribution. While the population from São Paulo presented C-bands at centromeric position in all chromosomes (Cardozo et al. 2011), the population of S. eurydice from northeastern Brazil showed heterochromatin at terminal regions of most chromosomes and centromeric regions of pairs 5 and 6 only (Fig. 1d). Telomeric C-bands were also reported in other hylids (Kasahara et al. 2003; Busin et al. 2006; Gruber et al. 2012). Similarly, NORs were also differentiated between both populations of $S$. eurydice once they were located at interstitial region of a single homologous in pair 11 whereas specimens from São Paulo presented terminal NORs at $11 \mathrm{q}$ besides interstitial cistrons in the same chromosome in one female (Cardozo et al. 2011). The physical mapping of $18 \mathrm{~S}$ rDNA confirmed the location of NORs, even though a single chromosome was marked by FISH.

Other cases of NOR polymorphism have been previously reported in anurans such as Hyla nana (Boulenger, 1889) (Medeiros et al. 2006), Hyla chrysocelis Cope 1880, Hyla versicolor LeConte, 1825 (Willey et al. 1989), Engystomops petersi Jiménez de la Espada, 1872 (Lourenço et al. 1998), Paratelmatobius poecilogaster Giaretta \& Castanho, 1990 (Lourenço et al. 2001), S. alter and S. hiemalis (Haddad \& Pombal, 1987) (Cardozo et al. 2011). According to some models of evolution of ribosomal genes in eukaryotes as well as experimental evidence in yeasts, the rDNA are tandemly arranged in chromosomes being particularly susceptible to unequal exchanges between sister chromatids (Eickbush and Eickbush 2007). This phenomenon could account for the presence of a larger (and active) cluster of $18 \mathrm{~S}$ rDNA in one homologue of pair 11 in S. eurydice. Nonetheless, other events such as errors during DNA replication could also lead to this polymorphic NOR state (Amaro-Ghilardi et al. 2008). Apparently, specimens bearing larger amounts of ribosomal DNA have been 
fixed in the analyzed population either by natural selection (if this NOR phenotype is somewhat adaptive) or by genetic drift.

The presence of heterozygous NORs $\left(\mathrm{Ag}^{+} / \mathrm{Ag}^{-}\right)$in S. eurydice might be related to sex, since this heteromorphic pattern was observed only in males. For instance, females and males of Gastrotheca riobambae (Fowler, 1913) were characterized by two and single NOR marks, respectively, mapped on X chromosomes (Schmid et al. 1983). If sexrelated NORs are also valid for $S$. eurydice, the sex chromosomes in this species would be morphologically homogeneous and further analyses should be carried out to identify putative mechanisms of sex chromosomal determination by other cytogenetic techniques.

Nonetheless, experimental evidence has shown that individuals of salamanders Plethodon cinereus (Green, 1818) and Xenopus laevis (Daudin, 1802) bearing heterozygous NORs $\left(\mathrm{Ag}^{+} / \mathrm{Ag}^{-}\right)$, independently on sex, are viable but their fertility is reduced since crosses between heterozygous specimens will produce unviable tadpoles bearing homozygous NORs (Schmid 1982). Therefore, it is possible that fertility of S. eurydice is also affected by this unusual pattern of NORs what remains to be investigated by inheritance studies in both natural and controlled conditions.

The interpopulation variation of NOR and C-banding pattern among populations of $S$. eurydice, associated with slight differences in vocalization between samples from northeastern and southeastern Brazil (Magrini et al. 2011), reinforces the necessity of a taxonomic review of this species.

In conclusion, the detailed cytogenetic characterization of $S$. auratus and S. eurydice showed that $S$. auratus shares some chromosomal traits with most of species in $S$. ruber clade, but diverges from the putatively closely related $S$. alter. The results in S. eurydice from Bahia revealed differences in chromosomal banding when compared to populations of southeastern Brazil, indicating the presence of cryptic species that should be systematically revised. Therefore, the chromosomal analyses in Scinax are potentially useful to both taxonomy and systematics of this group of anurans.

\section{Acknowledgments}

We thank Amanda Santiago, Rodrigo Araújo and Euvaldo Júnior for the collection and organization of specimens; Financial support to this work was provided by CAPES and CNPq. The specimens were collected with the permission of ICMBio (license number 28684-1).

\section{References}

Ananias F, Bombeiro AL, Silva CDB, Silva APZ, Haddad CFB, Kasahara S (2007) Cytogenetics of Eupemphix nattereri Steindachner, 1863 (Anura: Leiuperidae) and karyotypic similarity with species of related genera: taxonomic implications. Acta Zoologica Sinica 53(2): 285-293. 
Alves ACR, Gomes MR, Silva S (2004) Description of the tadpole of Scinax auratus (WiedNeuwied)(Anura, Hylidae). Revista Brasileira de Zoologia 21: 315-317. doi: 10.1590/ S0101-81752004000200026

Amaro-Ghilardi RC, Silva MJJ, Rodrigues MT, Yonenaga-Yassuda Y (2008) Chromosomal studies in four species of genus Chaunus (Bufonidae, Anura): localization of telomeric and ribosomal sequences after fluorescence in situ hybridization (FISH). Genetica 134: 159-168. doi: 10.1007/s10709-007-9218-6

Araújo OGS, Toledo LF, Garcia PCA, Haddad CFB (2009) The amphibians of São Paulo State, Brazil. Biota Neotropica 9: 197-209. doi: 10.1590/S1676-06032009000400020

Bruschi DP, Busin CV, Siqueira S, Recco-Pimentel SM (2012) Cytogenetic analysis of two species in the Phyllomedusa hypochondrialis group (Anura, Hylidae). Hereditas 40: 34-40. doi: 10.1111/j.1601-5223.2010.02236.x

Busin CS, Lima AP, Prado CPA, Strüssmann C, Siqueira S, Recco-Pimentel MS (2006) Chromosomal differentiation of populations of Lysapsus limellus limellus, L. l. bolivianus, and of Lysapsus caraya (Hylinae, Hylidae). Micron 37: 355-362. doi: 10.1016/j. micron.2005.11.009

Campos JRC, Ananias F, Haddad CFB, Kasahara S (2008) Karyotypic similarity among Barycholos ternetzi and five species of the genus Eleutherodactylus from southeastern Brazil (Anura, Brachycephalidae). Micron 39: 151-159. doi: 10.1016/j.micron.2006.11.001

Canelas MAS, Bertoluci J (2007) Anurans of the serra do Caraça, southeastern Brazil: species composition and pheno-logical patterns of calling activity. Iheringia 97: 21-26. doi: 10.1590/S0073-47212007000100004

Cardozo DE, Leme DM, Bortoleto JF, Catroli GF, Baldo D, Faivovich F, Kolenc F, Silva APZ, Borteiro C, Haddad CFB, Kasahara S (2011) Karyotypic Data on 28 Species of Scinax (Amphibia: Anura: Hylidae): Diversity and Informative Variation. Copeia 2: 251-263. doi: $10.1643 / \mathrm{CH}-09-105$

Eckbush TH, Eickbush DG (2007) Finely orchestrated movements: evolution of the ribosomal RNA genes. Genetics 175: 177-185. doi: 10.1534/genetics.107.071399

Faivovich J (2002) A cladistic analysis of Scinax (Anura: Hylidae). Cladistics 18: 367-393. doi: 10.1111/j.1096-0031.2002.tb00157.x

Frost DR (2014) Amphibian species of the world: an online reference. http://research.amnh. org/herpetology/amphibia/index.html. Archived by WebCite at http://research.amnh.org/ vz/herpetology/amphibia/Amphibia/Anura/Hylidae/Hylinae/Scinax [on 6 July 2014]

Green DM, Sessions SK (1991) Nomenclature for chromosomes. In: Green DM, Sessions SK (Eds) Amphibian Cytogenetics and Evolution. Academic Press, San Diego, 431-432. doi: 10.1016/B978-0-12-297880-7.50021-4

Gruber SL, Zina J, Narimatsu H, Haddad CFB, Kasahara S (2012) Comparative karyotype analysis and chromosome evolution in the genus Aplastodiscus. BMC Genetics 13: 1-9. doi: 10.1186/1471-2156-13-28

Hartmann MT (2002) Geographic Distribution. Scinax eurydice (Maracas Snouted Treefrog). Herpetological Review 33: 222-223.

Hatanaka T, Galetti PM (2004) Mapping of the 18S and 5S ribosomal RNA genes in the fish Prochilodus argenteus Agassiz, 1829 (Characiformes, Prochilodontidae). Genetica 122: 239-244. doi: 10.1007/s10709-004-2039-y 
Howell WM, Black DA (1980) Controlled silver-staining of nucleolus organizer regions with a protective colloidal developer. Experientia 8: 1014-1015. doi: 10.1007/BF01953855

Kasahara S, Silva AP, Gruber SL, Haddad CFB (2003) Comparative cytogenetic analysis on four tree frog species (Anura, Hylidae, Hylinae) from Brazil. Cytogenetic and Genome Research 103: 155-162. doi: 10.1159/000076304

Lourenço LB, Recco-Pimentel SM, Cardoso A (1998) Polymorfism of the nucleolus organizer regions (NORs) in Physalaemus petersi (Amphibia, Anura, Leptodactylidae) detected by silver staining and fluorescence in situ hybridization. Chromosome Research 6: 621-628. doi: 10.1023/A:1009253410553

Lourenço LB, Garcia PCA, Recco-Pimentel SM (2001) Cytogenetics of two species of Paratelmatobius (Anura: Leptodactylidae), with phylogenetic comments. Hereditas 133: 201-209. doi: 10.1111/j.1601-5223.2000.00201.x

Magrini L, Carvalho-e-Silva SP, Béda AF, Giaretta AA (2011) Calls of five species of the Scinax ruber (Anura: Hylidae) clade from Brazil with comments on their taxonomy. Zootaxa 51: 37-51.

Medeiros LR, Rossa-Feres DC, Jim J, Recco-Pimentel SM (2006) B chromosomes in two brazilian populations of Dendropsophus nanus (Anura, Hylidae). Genetics and Molecular Biology 29: 257-262. doi: 10.1590/S1415-47572006000200010

Mercês EA, Juncá FA (2012) The tadpole of Scinax juncae Nunes e Pombal, 2010 (Anura, Hylidae). Zootaxa 3416: 41-43.

Nunes I, Pombal JJP (2010) A new Scinax Wagler (Amphibia, Anura, Hylidae) from the Atlantic Rain Forest remains of southern state of Bahia, North-eastern Brasil. AmphibiaReptilia 31: 347-353. doi: 10.1163/156853810791769482

Nunes I, Pombal JPP (2011) A new snouted treefrog of the speciose genus Scinax Wagler (Anura, Hylidae) from Northeastern Brazil. Herpetologica 67: 80-88. doi: 10.1655/HERPETOLOGICA-D-10-00026.1

Nunes I, Kwet A, Pombal JPP (2012) Taxonomic revision of the Scinax alter species complex (Anura: Hylidae). Copeia 3: 554-569. doi: 10.1643/CH-11-088

Pinkel D, Straume T, Gray JW (1986) Cytogenetic analysis using quantitative, high sensitivity, fluorescence hybridization. Proceedings of the National Academy of Science of the United States of America 83: 2934-2938. doi: 10.1073/pnas.83.9.2934

Pombal JJP, Bastos RP, Haddad CFB (1995) Vocalizaçóes de algumas espécies do gênero Scinax (Anura, Hylidae) do sudeste do Brasil e comentários taxonômicos. Naturalia 20: 213-225.

Schmid M (1978) Chromosome banding in Amphibia I. Constitutive heterochromatin and nucleolus organizer regions in Bufo and Hyla. Chromosoma 66: 361-388. doi: 10.1007/ BF00328536

Schmid M (1980) Chromosome banding in Amphibia. IV. Differentiation of GC- and ATrich chromosome regions in Anura. Chromosoma 77: 83-103. doi: 10.1007/BF00292043

Schmid M (1982) Chromosome banding in Amphibia. VII Analysis of the structure and variability of NORs in Anura. Chromosoma 87(3): 327-344. doi: 10.1007/bf00327634

Schmid M, Haaf T, Geile B, Sims S (1983) Chromosome banding in Amphibia. VIII. An unusual XY/XX-sex chromosome system in Gastrotheca riobambae (Anura, Hylidae). Chromosoma 88(1): 69-82. doi: 10.1007/bf00329505

Siqueira S, Ananias F, Recco-Pimentel SM (2004) Cytogenetics of three Brazilian species of Eleutherodactylus (Anura, Leptodactylidae) with 22 chromosomes and re-analysis of mul- 
tiple translocations in E. binotatus. Genetics and Molecular Biology 27: 363-372. doi: $10.1590 /$ S1415-47572004000300010

Siqueira S, Aguiar O, Strussmann C, Del-Grande ML, Recco-Pimentel MS (2008) Chromosomal analysis of three Brazilian "Eleutherodactyline" frogs (Anura: Terrarana), with suggestion of a new species. Zootaxa 1860: 51-59.

Sumner AT (1972) A simple technique for demonstrating centromeric heterochromatin. Experimental Cell Research 75: 304-306. doi: 10.1016/0014-4827(72)90558-7

White TJ, Bruns T, Lee S (1990) Amplification and direct sequencing of fungal ribosomal RNA genes for phylogenetics. In: Innis MA, Gelfand DH, Sninsky JJ, White TJ (Eds) PCR Protocols: a guide to methods and applications. Academic Press, New York, 315-322. doi: 10.1016/b978-0-12-372180-8.50042-1

Willey JE, Little ML, Romano MA, Blount DA, Cline GR (1989) Polymorphism in the location of the $18 \mathrm{~S}$ and $28 \mathrm{~S}$ rRNA genes on the chromosomes of the diploid-tetraploid treefrogs Hyla chrysoscelis and H. versicolor. Chromosoma 97: 481-487. doi: 10.1007/BF00295033 